\title{
Preconditions of Formation \\ of the Arctic Aqua-Territorial \\ Industrial Complex on the Basis \\ of the Development of the Natural-Resources \\ Potential of the Khatanga-Anabar Region
}

\author{
Nikolai G. Shishatsky ${ }^{a *}$, Elena A. Bryukhanova ${ }^{a}$, \\ Valery S. Efimov ${ }^{b}$ and Aleksandr M. Matveev ${ }^{\mathbf{a}}$ \\ a Institute of Economics and Industrial Engineering \\ of $S B R A S$ \\ 50/45 Akademgorodok, Krasnoyarsk, 660036, Russia \\ ${ }^{b}$ Siberian Federal University \\ 79 Svobodny, Krasnoyarsk, 660041, Russia
}

Received 14.06.2016, received in revised form 19.07.2016, accepted 21.08.2016

The article analyzes the current status and problems of socio-economic development of the KhatangaAnabar region located in the Arctic zone of Eastern Siberia in the territory of two subjects of the Russian Federation (Krasnoyarsk Territory (Krai) and the Republic of Sakha (Yakutia)), in the basins of the Khatanga and Anabar Rivers flowing into the Laptev Sea of the Arctic ocean. The authors studied possibilities, limitations and prospects for the implementation of the top-priority investment projects of development of mineral resources in the region. The article discusses the expediency of forming the aqua-territorial industrial complex (ATIC) based on the use of integrated transport logistics of the Northern Sea Route and rational power layouts in the region. It also examines scientific and methodical, organizational and economic problems on the development of the formation strategy of the Khatanga-Anabar ATIC.

Keywords: Khatanga-Anabar region, investment projects, transport and energy infrastructure, Northern Sea Route, aqua-territorial industrial complex (ATIC), ATIC strategy formation.

The study was sponsored by the Russian Foundation for Humanities and the Regional State Autonomous Institution "Krasnoyarsk Regional Foundation for Scientific and Technical Activities" within the framework of the research project "Development of long-term scenarios and organizational-economic mechanisms for the development of the Arctic zone of the Krasnoyarsk Territory and assessment of their impact on a social and economic state and dynamics of the Krasnoyarsk Territory" (project No. 16-12-24007)

DOI: 10.17516/1997-1370-2016-9-10-2507-2524.

Research area: economics.

(C) Siberian Federal University. All rights reserved

* Corresponding author E-mail address: nik@ksc.krasn.ru 
The development of the Northern and Arctic regions is one of the most important and most difficult problems for Russia in the $21^{\text {st }}$ century. All this makes it necessary to conduct socioeconomic, scientific and technological studies in order to determine a map of perspective development projects of the Russian North. It is necessary to determine possibilities of the use of the available natural resources to establish modern high-tech industries, to identify mechanisms for organization of the development processes, including a mechanism for the public-private partnership.

This article discusses the possibilities and limitations of development of the KhatangaAnabar economic region located in the northern territories of the Krasnoyarsk Territory and the Republic of Sakha (Yakutia).

\section{General characteristics of the Khatanga-Anabar region}

Economic-geographical situation and administrative-territorial division

The Khatanga-Anabar region is located in the Arctic zone of Eastern Siberia. Its territory includes basins of the Khatanga and Anabar Rivers flowing into the Laptev Sea of the Arctic Ocean.
The long-term specialization and the possibility of the integrated economic development of territories close to the Northern Sea Route in the western waters of the Laptev Sea identified commonality of their resource potential, development prerequisites, socioeconomic problems and their solutions. These factors conditioned the feasibility of considering these territories as a single economic and geographic region and predetermined its name the Khatanga-Anabar region.

The total area of the Khatanga-Anabar region is 482,000 square kilometers, population of 8902 people, including 6919 representatives of the indigenous peoples of the North. ${ }^{1}$

The region includes one municipal district of the Republic of Sakha (Yakutia) (Anabarsky District (Ulus)) and two rural settlements - the Khatanga settlement of the Taimyr municipal district of the Krasnoyarsk Territory and Zhilindinsky Village (Nasleg) of the Oleneksky District (Ulus) of the Republic of Sakha (Yakutia) (Table 1).

Geographical location of the KhatangaAnabar region is characterized by the remoteness from industrial centers and markets for manufactured products (Table 2).

Table 1. Administrative-territorial division and population of the Khatanga-Anabar region (as of January 1, 2016)

\begin{tabular}{|l|c|c|c|c|}
\hline \multicolumn{1}{|c|}{ Administrative-territorial units } & Administrative centre & $\begin{array}{c}\text { Number of } \\
\text { settlements }\end{array}$ & $\begin{array}{c}\text { Area, thousand } \\
\text { square km }\end{array}$ & $\begin{array}{c}\text { Population, } \\
\text { people }\end{array}$ \\
\hline \multicolumn{5}{|c|}{ Krasnoyarsk Territory } \\
\hline $\begin{array}{l}\text { The Khatanga settlement of the Taimyr } \\
\text { municipal district }\end{array}$ & Khatanga & 10 & 336,4 & 4788 \\
\hline \multicolumn{3}{|c|}{ Republic of Sakha (Yakutia) } \\
\hline Anabarsky Ulus & Saskylakh & 3 & 55,6 & 3430 \\
\hline $\begin{array}{l}\text { Zhilindinsky Nasleg of the Oleneksky } \\
\text { Ulus }\end{array}$ & Zhilinda & 1 & 90,0 & 684 \\
\hline Total & & 14 & 482,0 & 8902 \\
\hline
\end{tabular}

Note: the table was compiled by the authors using "Indicators database for municipalities". URL: http://www.gks.ru/free_doc/ new_site/bd_munst/munst.htm 
Table 2. Table of distances ( $\mathrm{km}$ on the map)

\begin{tabular}{|l|c|c|c|c|c|}
\hline & Krasnoyarsk & Yakutsk & Saint-Petersburg & Murmansk & Vladivostok \\
\hline Khatanga & 1914 & 1551 & 3300 & 2475 & 3597 \\
\hline Saskylakh & 2046 & 1265 & 3696 & 2838 & 3366 \\
\hline Zhilinda & 1914 & 1155 & 3729 & 2904 & 3234 \\
\hline
\end{tabular}

The region is characterized by the following factors:

- extremely high territorial disunity and inaccessibility of settlements, remoteness from the administrative centers of settlements;

- between settlements there are no permanent roads, inter-settlement and inner-settlement infrastructure connections; inter-settlement social and cultural service to the public is hindered.

Territories of the Khatanga-Anabar region are cut off from important transport communications. The region does not have yearround communication with the nearest railway terminals (Yakutsk, Ust'-Kut, Krasnoyarsk (Lesosibirsk)), there are no year-round water transport links, and there is no reliable road transport communication between settlements.

The possibilities of sea transport are not used because of the lack of development of transport along the Northern Sea Route and limitations of the existing sea ports of the Eastern Arctic.

Prospects for the inclusion of the region's economy into the global world are associated primarily with the development of the Northern Sea Route (NSR) and the creation of a NSRoriented transport and logistics hub in the region. In a longer term the development of the region can be carried out on the basis of the formation of year-round ground lines of communication.

\section{Current situation in the economy}

Extreme climatic conditions (duration of the heating season in the region ranges from 296 days (Zhilinda) to 325 days (Yuryung-Khaya, Novorybnaya, Syndassko)), low population density, high resource intensity, a focal nature of industrial and economic development, the use of a decentralized system of electricity and heat supply, significant distance from the major economic centers and dependence of life activity on the supply of goods to northern Russia cause a significant value appreciation in the socioeconomic development of the Khatanga-Anabar region.

Currently, the level of budgetary expenditure for 1 resident in the region amounts to 200-220 thousand rubles per year. It is much higher than the average value in the municipalities of the European part of the country (20-25 thousand rubles), Siberian Federal District (28.1 thousand rubles) and several times higher than in the regions of the Ural (53.0 thousand rubles) and Far East (84.5 thousand rubles) Federal Districts².

The situation is compounded by the fact that during the years of market reforms there has been a serious dilapidation, physical and moral depreciation of fixed assets of all vital sectors of the region's areas: transport, power supply, social infrastructure and housing-public utilities.

Revenues in the main economic activities of the region (wild deer hunting, fishing, fur trapping, reindeer herding) are not able to provide the required level of budgetary expenditures. The average annual income of a person employed in the sector is less than $8-10$ thousand rubles per month, when the value of the minimum subsistence income in the Khatanga rural settlement is 28.8 thousand rubles (in the $2^{\text {nd }}$ quarter of 2016) ${ }^{3}$ and in the Anabarsky and Oleneksky Uluses it is 18.4 thousand rubles (in the $1^{\text {st }}$ quarter of 2016) ${ }^{4}$. 
A certain aid to the population and local budgets of the Anabarsky and Oleneksky Uluses is the extraction of alluvial diamonds, which is carried out by the "Almazy Anabara" company (subsidiary of JSC "ALROSA") in these areas. Volumes of production of the "Almazy Anabara" company (15,489.4 million rubles) correspond to the level of 600 largest Russian companies, and net profit (1,697.4 million rubles) - to the level of 200 largest Russian companies ${ }^{5}$.

At the same time, the Uluses' share (taxes to the local budgets, payment of wages to workers from the local community) gets no more than $2-3 \%$ of the diamond mining company's income generated in the region, and the rest is distributed to the federal and republican budgets for the payment of wages to employees - residents of other regions of the republic, as well as the implementation of investment programs of the company.

According to estimates, the total average number of shift workers in the "Almazy Anabara" company, which is involved in the territory of the Anabarsky and Oleneksky Uluses, is about 1.21.4 thousand people (varies throughout the year from 1 thousand people to 3 thousand people). However, the proportion of the local population in this number is not more than $20-30 \%$, and the rest of the shift workers of the company are formed by the residents of other regions of the Republic of Sakha (Yakutia) ${ }^{6}$.

Under these conditions, budgetary subsidies and grants-in-aid are the main source of financing of life sphere in the region. $35-40 \%$ of the incomes of local budgets are formed at the expense of grants-in-aid, and the share of own tax and nontax revenues does not exceed $20-25 \%$.

\section{Priority investment projects}

Prospects of the Khatanga-Anabar region are associated with the development of significant reserves of solid minerals and hydrocarbon resources, part of which has federal significance. Among the top-priority development projects there are: Tomtor deposit of rare-earth metals (REM); development of the Laptev Sea shelf and coastal waters of the Khatanga and Anabar Gulfs; development of the Ebelyakh-Gusinyi deposit of alluvial diamonds; development of the Kotui coal deposit; development of the Popigai deposit of impact diamonds (Fig. 1).

\section{Development of the Tomtor deposit of rare-earth metals (REM)}

Reasonability and feasibility of development

Development of the Tomtor deposit is one of the main elements of the development program of mining and processing of rare-earth metals till 2020 (under the framework of the Russian State Program "Development of manufacturing industry and improvement of its competitiveness in the period up to 2020" approved by the Resolution of the Russian Federation Government No. 328 dated 04/15/2014) ${ }^{8}$.

Reserves of only one Burannyi section (comprising about a third of all the resources of the deposit) can provide domestic and export needs of Russia planned by the program for hundreds of years. At the same time, the ores of the deposit (including the ratio of world prices of rare items) are the most attractive among all Russian deposits and significantly (by more than 2 times) excel in this parameter the ores of one of the world's largest deposits of rare-earth metals Baiyun Obo (China).

Technological and transport scheme of development

For the development of the deposit, the Siberian Branch of the Russian Academy of Sciences (Institute of Geology and Mineralogy (IGM), Institute of Chemistry and Chemical Technology (ICCT) and the Institute of Economics 


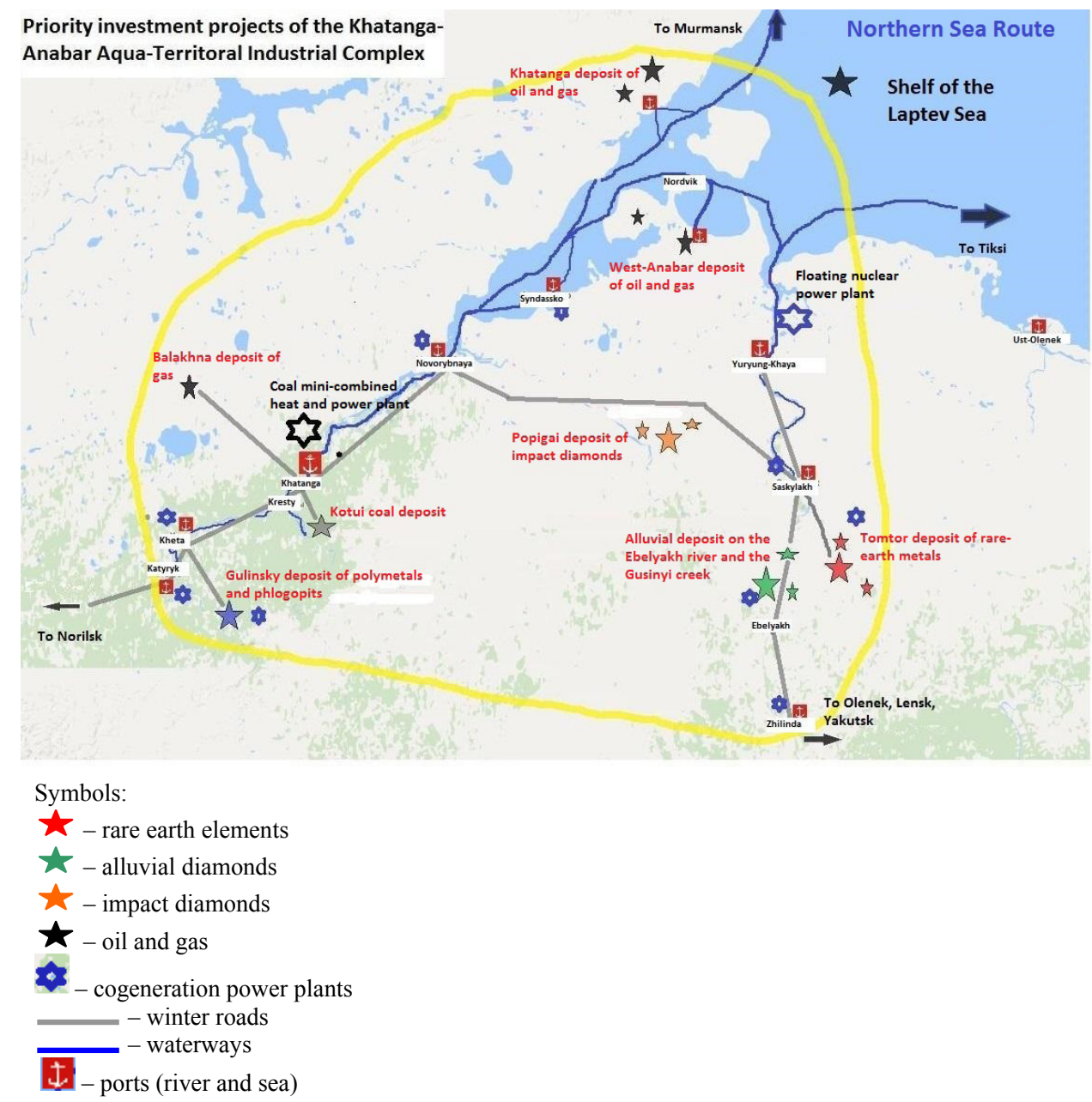

Fig. 1. Overview map of development projects of mineral resources in the Khatanga-Anabar region

and Industrial Engineering (IEIE)) proposed a three-tier production chain: 1) ore production (at the first stage - up to 100- 200 thousand tons, at the second stage - to 500-1000 thousand tons); 2) processing of the base ore to produce a collective carbonate of rare-earth elements (REE or individual oxides of rare-earth elements); 3) chain separation of oxides and individual rareearth metals and production of more valuable final products (Pokhilenko et al, 2014).

Primary processing of the Tomtor ore can be implemented at the Zheleznogorsk MCC (Mining and Chemical Plant) (ore transportation from Tomtor to Zheleznogorsk by winter road to the Yuryung-Khaya port and further by sea vessels), and final processing - at the plant for the production of rare metals (Novosibirsk or Krasnoyarsk) (Iatsenko).

Selection of specific technological schemes of deep and complex processing of primary concentrates, as well as the establishment of necessary facilities to obtain the final products require additional research.

\section{Prospects for the project}

The project that is worth about 1 billion dollars and calculated for the period up to 20212023 provides for the establishment of mining production in Tomtor with capacity of 100 thousand tons of ore, development of monazite 
dumps in Krasnoufimsk (Sverdlovsk region) and creation of a hydrometallurgical plant (location area is not defined) with capacity of 4.5 thousand tons of ferroniobium and 10 thousand tons of REM oxides (REO) per year.

Currently, the joint venture "TriArk Mining" (under the auspices of the State Corporation Rostec and ICT Group) has launched the development of the richest section of the Tomtor deposit - "Burannyi"10.

\section{Weaknesses and risks of the project}

The Tomtor ores are radioactive due to the presence of uranium and thorium. This requires compliance with the relevant safety precautions when working with them and requires additional costs for disposal of radioactive waste.

The emergence of new foreign competitors in the countries of South East Asia (North Korea, Japan) and the development of their own hightech production of REM and products using them, create additional competitive challenges for the Tomtor project.

Prices for REM are fluctuated significantly. High volatility of prices for REM creates additional difficulties in attracting investment in this project.

Insufficient development of high-tech industries forming the demand for rare-earth metals in the domestic market increases risks of low liquidity of the obtained marketable products.

\section{Oil and gas complex}

(development of the Laptev Sea shelf and coastal waters

\section{of the Khatanga and Anabar Gulfs)}

\section{Reasonability and feasibility of formation}

According to the US Geological Survey estimates, the North-Western and the Eastern shelves of the Laptev Sea are among the 25 largest Arctic provinces in the amount of hydrocarbon reserves in the world occupying the $20^{\text {th }}$ and the $8^{\text {th }}$ place in the resource potential respectively. Their probable reserves amount to 1.425 million tons of oil equivalent ( $2.5 \%$ of total hydrocarbon resources in the Arctic) ${ }^{11}$.

Taking into account the available resources (with a coefficient of extraction 0.3-0.4) in the region, in the future it is possible to create a large oil and gas complex (with a peak production rate of 5-6 million tons of hydrocarbons per year) thus ensuring its continued stable functioning for a few decades.

Location of the Laptev Sea shelf in the region of the Northern Sea Route and in the area of transport accessibility of the coastal infrastructure of the Khatanga-Anabar region (Khatanga, Yuryung-Khaya ports) provides the necessary conditions for stable and competitive production and transportation of oil to areas of consumption.

\section{Technological and transport scheme}

In order to arrange oil and gas deposits in the waters of the Laptev Sea, a technological scheme for the development of the Prirazlomnoe deposit in the Pechora Sea can be used on the basis of the marine ice-resistant stationary platform $(\mathrm{MISP})^{12}$.

MISP (with capacity of up to 6 million tons of oil per year) is designed for year-round operation for 25 years in extreme natural climatic conditions under cyclic loads of drifting ice.

The transport scheme of the project involves the use of multifunctional icebreaking vessels and two shuttle tankers.

The coastal infrastructure was created for efficient production management and delivery of shift personnel and cargo to the platform. It includes:

- transshipment base with a field camp Varandei for the temporary placement of staff;

- supply base and support base in Murmansk. 


\section{Prospects for the project}

A number of domestic companies have already indicated their interest in geological exploration and development of the Laptev Sea shelf subsoil. At the end of 2015, Rosneft and LUKOIL shared the East Taimyr deposit in the Khatanga Gulf. The "Rosneft" company has received the marine sector of the deposit (Khatanga sector) with the forecast resources of 82.8 million tons of oil and 228.2 billion cubic meters of gas. LUKOIL has acquired a license for exploration and development of the Coastal (East Taimyr) sector. The resources of the sector consist of 4.5 million tons of oil, 9.3 billion cubic meters of gas, 0.5 million tons of condensate ${ }^{13}$.

Further development will depend on the speed of verification of the scope of the oil potential of the acquired sectors, as well as the hydrocarbon market conditions. Taking into account the period of further exploration before making an investment decision, as well as the duration of the development and approval of projects, construction and installation of the platform, the tanker and the icebreaker fleet, arrangement of the necessary marine and coastal infrastructure, the beginning of exploitation of the deposit and the production of the first tons of oil in the most optimistic scenario is not expected until 2025.

\section{Weaknesses and risks of the project}

A hydrocarbon potential of the Eastern Arctic shelf has not practically been studied. Potential oil and gas waters of the Laptev Sea are very poorly explored geologically.

Density of seismic exploration works of the Laptev Sea $(0.08$ lin $\mathrm{km} / \mathrm{sq} \mathrm{km})$ is significantly lower than in the Western Arctic waters (in the Kara Sea it is 0.21 lin $\mathrm{km} / \mathrm{sq} \mathrm{km}$, in the Barents and Pechora Seas -0.5 lin $\mathrm{km} / \mathrm{sq} \mathrm{km}$ ), as well as in the Norwegian part of the Barents sea (1.01 lin $\mathrm{km} / \mathrm{sq} \mathrm{km}$ ) (Konoplianik et al., 2016).
Moving to a level of exploration of at least the Barents and Pechora Seas will be essentially hindered due to climatic factors and will lead to a significant appreciation of the cost of developing the explored deposits.

Transport conditions for the functioning of the oil platform in the Laptev Sea are more complex (compared to the "Prirazlomnoe" deposit in the Pechora Sea). In order to organize a year-round vessel escort in the area, the icestrengthened vessels will be required (Arc7 and above). However, the nuclear-powered icebreakers of this class will not be able to enter the shallow mouth of the Khatanga River due to their draft. Therefore, it is necessary to build a special fleet to use the Khatanga port year-round.

The pricing environment remains unfavorable in the oil market. Profitability of the project for the development of the "Prirazlomnoe" deposit was substantiated at an oil price of $\$ 100$ per barrel, while in 2015-2016 it did not exceed $\$ 50$ per barrel.

\section{Development \\ of the Ebelyakh-Gusinyi deposit of alluvial diamonds}

A long-term development strategy of the leading Russian and world diamond mining company "ALROSA", including its subsidiary company "Almazy Anabara" is based on the priority development of the large deposits of diamonds prepared for the industrial development.

The alluvial deposit on the Ebelyakh river and the Gusinyi creek (hereinafter Ebelyakh-Gusinyi) is Russia's largest deposit of alluvial diamonds with explored reserves of $25.6 \mathrm{mln}$. carats $(2.1 \%$ of the total balance reserves of the Russian diamonds). In the quality and content of diamonds, the EbelyakhGusinyi alluvial deposits (1.43 carats $\left./ \mathrm{m}^{3}\right)$ exceed actively developed alluvial objects of Ghana (1 ct/ $\left.\mathrm{m}^{3}\right)$ and Guinea $\left(0.7 \mathrm{ct} / \mathrm{m}^{3}\right)^{14}$. 
Development of this deposit will allow the "Alrosa" company (and "Almazy Anabara") to maintain and strengthen its position in the diamond market for a few more years.

\section{Technological and transport scheme}

A technological and transport scheme of the development project of the Ebelyakh-Gusinyi deposit is based on the actual experience of commercial operation by the "Almazy Anabara" company of similar alluvial diamond deposits in the Oleneksky and Anabarsky Uluses (alluvial deposits of the Morgogor, Mayat, Kula, Olom, Kurung-Yuryakh rivers).

The development of alluvial deposits of the "Almazy Anabara" company is based on a three-stage scheme: 1) carrying out stripping works with the extraction of diamond sands; 2) transportation and primary processing of sands into a concentrate at the sites of mobile sorting and processing facilities; 3) transportation and final extraction of diamonds in the production units of the seasonal concentration plant (SCP) (Udachninskyi GOK).

This technology has proven its economic efficiency and environmental safety. ${ }^{15}$

\section{Prospects for the project}

The project is being carried out according to plan. In 2014, the Ebelyakh-Gusinyi sector reached the planned parameters of diamond-bearing sands processing - 1.6-1.8 million cubic meters per year (2.2-2.5 mln. carats of diamonds).

The total amount of recoverable diamonds during service of the deposit in 2014-2021 will be $16.7 \mathrm{mln}$. carats $(2.3 \mathrm{mln}$. carats per year), including on the Ebelyakh River - $13.4 \mathrm{mln}$. carats $(1.7 \mathrm{mln}$. carats per year) and on the Gusinyi Creek - $3.3 \mathrm{mln}$. carats (600 thousand carats per year).

If the deposits are developed in accordance with the schedule of the project, the reserves of the Gusinyi Creek will be exhausted by 2019. The development of the Ebelyakh River deposit can be extended to $2027 .^{16}$

\section{Weaknesses and risks of the project}

Threats to the project are related to the general trends of the development of the diamond market and long-term downward trends in the average prices for natural diamonds.

According to some predictions, in 1520 years natural diamonds will completely give up their place in the market to synthetic diamonds. ${ }^{17}$

There are general risks associated with environmental protection, labor protection and industrial safety in the area of mining fields on the Ebelyakh River and the Gusinyi Creek.

\section{Development of the Kotui coal deposit}

\section{Reasonability and feasibility}

The overall demand for coal for heating needs of the Khatanga settlement is 40-50 thousand tons of coal per year.

Delivery of such quantity of coal under conditions of an underdeveloped transport infrastructure and remoteness from the coalmining regions (Norilsk Industrial Region, Sakha (Yakutia), Kemerovo Region, Murmansk, etc.) creates high risks to local livelihoods and is very expensive.

However, the territory of the Khatanga settlement has significant reserves of its own fossil coals. Development of these reserves will reduce the costs of provision of coal and increase reliability of heat supply of the economy and population of the region.

Reserves of the Kotui coal deposit (40 $\mathrm{km}$ from Khatanga) account for more than 320 million tons and allow for reliable long-term supply of coal for enterprises and the population of the Khatanga settlement. ${ }^{18}$ 


\section{Prospects for the project}

Despite the reasonable economic and high social efficiency, the Kayak-2 mine construction project has not been realized to the present time and is not planned to be implemented by the stakeholders.

The main reason for this is that the main beneficiary of the project - regional and local budgets - cannot become an investor due to deficiency (limitation) of their financial capabilities. For private investors, the project is not of much interest due to the fact that the budget savings for the "northern delivery" associated with the project are out of their "pocket". The project-funding problem can be successfully solved by the creation of an effective mechanism of the public-private partnership.

\section{Development of the Popigai deposit of impact diamonds}

\section{Reasonability and feasibility}

Currently, the worldwide sales volume of the industrial-use diamonds (15.7 billion dollars) is 1.5 times higher than the sales volume of gem diamonds and is developing much faster. It is predicted that in the period from 2016 to 2023 the industrial-use diamond market will grow at an average annual rate of $7 \% .^{19}$

These circumstances actualize the issues associated with the development of the unique Popigai deposit of impact diamonds.

The deposit has giant reserves of technicalquality diamonds (impact-type diamonds). The estimated total quantity of diamonds contained in the Popigai meteorite crater is several trillion carats.

These volumes will be enough to meet the current needs of the world technical diamond market (10 billion carats per year) for hundreds of years.

\section{Technological and transport scheme}

Development of the Popigai deposit does not have any technical and technological difficulties.
Here, a technological and organizational scheme that has been used successfully in the deposits of alluvial diamonds in Anabarsky and Oleneksky Uluses for many years, may be implemented.

The primary objects for the development may be the two explored sectors - Skalnyi and Udarnyi ( $0.5 \%$ of the total area of the deposit). Their total reserves $(\mathrm{A}+\mathrm{B}+\mathrm{C} 1$ and $\mathrm{C} 2)$ reach almost 268 billion carats and the average diamond content in the ores is unique (2-3 times higher than the maximum concentrations of kimberlite diamond pipes) $-18.47 \mathrm{ct} / \mathrm{t}$ and $7.13 \mathrm{ct} / \mathrm{t}$ respectively ${ }^{20}$.

Given such high concentration of diamonds, their production costs could amount to 2.5-3 \$/ carat.

Given the small load capacity of the Popigai deposit products, air transportation is the most advantageous for its delivery. Depending on the site of final processing of the obtained diamond concentrate, there can be different options of routes: Saskylakh - Udachnyi (Mirnyi) Novosibirsk or Saskylakh - Khatanga Krasnoyarsk (Kriukov, 2016).

\section{Prospects for the project}

Preliminary estimates show that the use of impact diamonds of the Popigai deposit can become the basis of formation of the industrialuse diamonds market of a new generation and products based on them.

Formation of such a market requires the development of a long-term system strategy and conduction of a wide range of scientific and technological research works.

A concept of such a strategy was proposed by scientists of the SB RAS. The final stage of its implementation would be to create a technological platform for processing and use of diamonds for the purpose of technical and scientific application of natural micro-, nano-polycrystal diamonds on the basis of the scientific and technical complex of the SB RAS and the enterprises of the Republic 
of Sakha (Yakutia) and the Krasnoyarsk Territory (Pokhilenko \& Kriukov, 2012).

\section{Implementation of the development projects of the region as the basis for the formation of the Khatanga- Anabar aqua-territorial industrial complex (KhA ATIC)}

Features of the current socio-economic situation, as well as the complexity of tasks related to the implementation of the development projects of the Khatanga-Anabar region, necessitate consideration of its development strategy based on the use of the result-oriented approach and the concept of aqua-territorial industrial complexes (ATIC) focused on the implementation of programs (strategies) of the development of sea coast areas (Baklanov, 1979, 1987; Bondarenko et al, 2012).

The objective prerequisites for the formation of ATIC in the Khatanga-Anabar region are the following factors:

- objects of the regional specialization industries are operating on the shore and in the sea waters;

- two blocks are clearly allocated in the structure of the economic activity: territorially settled (industrial activity on the shore) and aqua-territorially migrating (mobile production activity in the waters);

- block joining into a single unit is provided by the sea transport. In general, the ATIC includes sea (and river) ports, industrial enterprises, coastal settlements;

- formation of the industrial structure of the ATIC is in compliance with the key requirement: objects of maritime transport, oil and gas production in the shelf area and on land, mining companies do not simply co-exist in the territory, but also interact with each other;

- effectiveness of the interaction is manifested not only in the increase of the level of technical and technological potential of economic activity, but also in the strengthening of the revenue side of the budget of regions that will form the ATIC (Krasnoyarsk Territory and the Republic of Sakha (Yakutia));

- an important role in the economy of the region is given to the foreign economic relations.

The main advantage of the implementation of regional development projects in the ATIC format is a complex approach that expands cooperation ties and effective cooperation between the participants through the integration (in rational scale) of production (transport, energy) and social infrastructure. This can contribute to cheapening of the projects, appreciation of the added value and in the end -the increase in the revenue side of the budget of administrative units. As a consequence, it can create better conditions for the solution of additional economic, social and environmental tasks. Another important result should be the emergence of real prerequisites for the creation and improvement of an investment climate conducive to investment, including foreign investments.

\section{Transport infrastructure}

A key factor in the effective implementation of the resource development projects and economic development of the Khatanga-Anabar region is the establishment of intensive and reliable transport links with major Russian and world commodity markets. Despite the well-known difficulties of its economic and geographical position, the Khatanga-Anabar region has good opportunities to meet this challenge.

Prospects for the region's entry into the external economic space are related to the development of the transport corridor - "North Sea Route", inclusion of the Khatanga and Yuryung-Khaya ports and formation of the corresponding port and coastal infrastrucure. 


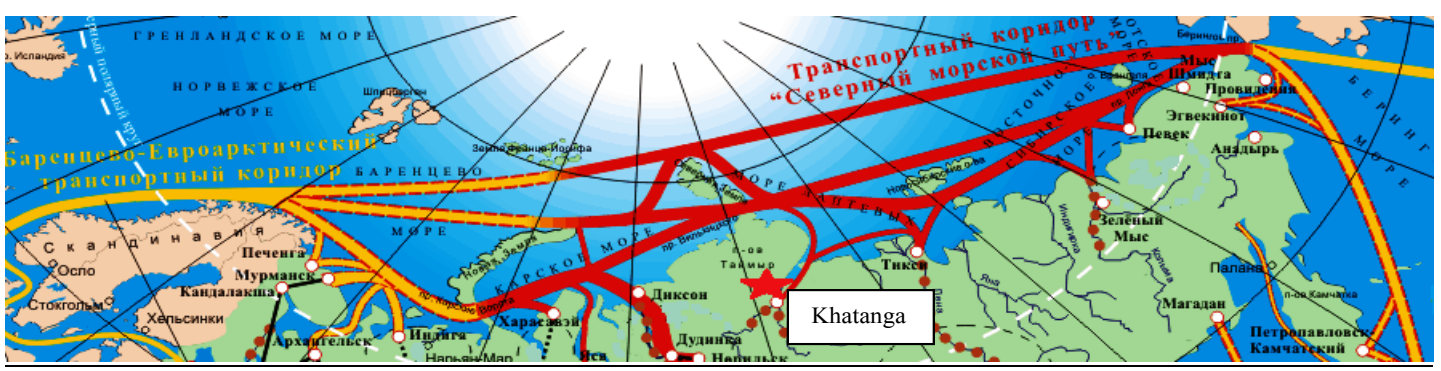

Fig. 2. Khatanga port in the system of Russian transport corridors in the Arctic Ocean (Peresypkin, Iakovlev, 2006)

Currently, the Khatanga seaport (Fig. 2) has a low level of development, which is comparable to the level of social and economic development of the areas of the Khatanga settlement it supports.

Port capacity is 95 thousand tons per year (maximum turnover of 350 thousand tons was recorded in 1976). ${ }^{21}$

The port processes food and refrigerated cargo, a variety of general cargo for the Arctic settlements, timber, bulk cargo (coal, sand and gravel mix), oil cargo. The port also handles regular passenger traffic along the Khatanga River and its tributaries to the Khatanga settlements.

The port operates only during the summer season (from mid-June to late September). The port provides access to vessels with a draft of 4.6 $\mathrm{m}$. Cargo transfer from sea ships to river ships is carried out at the Kosistyi Cape.

The development of oil and gas deposits on the territory of the Khatanga settlement and the Laptev Sea shelf will be accompanied by an increase in the volume and intensity of freight and passenger traffic and will require substantial renovation and increase in port capacity and creation of a major transportation and logistics hub on its basis (Fig. 3).

Prospects of a transport-logistics hub on the basis of the Khatanga seaport include: ${ }^{22}$

1. Reconstruction of the port complex taking into account the requirements of the Maritime Doctrine for the Unification of the infrastructure for military and economic needs, modernization and expansion of the seaport;

2. Expansion of navigation on small rivers;

3. Development of warning and communication systems on the Northern Sea Route and all water routes in its area of influence:

- construction of digital radio stations;

- modernization, reconstruction and equipment of facilities of the air-navigation infrastructure. Introduction of the "GLONASS/ GPS" system;

- expansion of the aerological station network;

- updating hydrographic maps of waters of the Khatanga Gulf and an approach to the Khatanga seaport, reconstruction of buildings and facilities of the hydrographic database;

4. Reconstruction and inclusion of the Khatanga airport to the list of alternate airports to ensure safety for flights along cross-polar routes and along organized regional airline.

The pace of development of the Khatanga transport and logistics center will be determined by the timing and scale of the development of oil fields.

Given the fact that the practical implementation of the oil project is not expected before 2020-2025, establishment of the Khatanga transport and logistics hub should be divided into two stages: at the first stage (before 2020- 


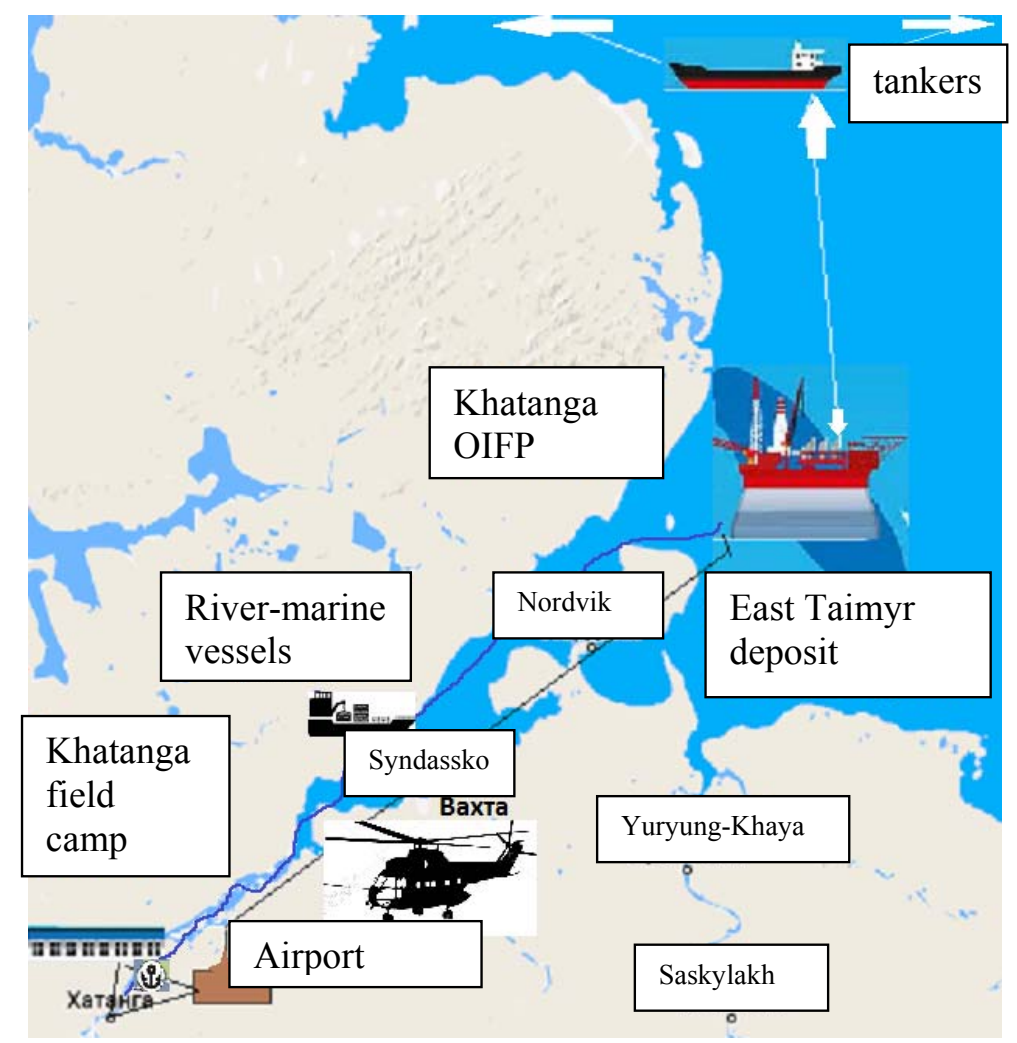

Fig. 3. The development of transport and maintenance service in the Khatanga settlement during the development of hydrocarbon deposits of the shelf

2025) it is necessary to ensure reconstruction and modernization of the existing infrastructure, at the second stage (after 2025) - to start to increase its capacity and expand the composition - to establish a repair and maintenance base of the commercial and specialized fleet; a base for establishment and maintenance of high-latitude expeditions; to organize tourist routes with the development of an appropriate infrastructure.

Along with the Khatanga port, the external transport links will also be provided through another sea port in the region - Yuryung-Khaya that will receive the appropriate development as a cargo-transfer base for the development of the Ebelyakh alluvial diamond deposit, the Tomtor deposit of rare earth metals, the Popigai deposit of impact diamonds and local AIC enterprises. ${ }^{23}$

Inter-municipal transport links will be developed in winter - by the main winter roads
Dudinka-Norilsk-Khatanga (750 km), KhatangaPopigai-Syskylakh (400 km) and OlenekSyskylakh-Yuryung-Khaya (730 km), as well as the adjoining local winter roads, in a short period of summer navigation - on the rivers of Khatanga and Anabar and their tributaries.

In the air transport there is a need for reconstruction and construction of airports, airstrips and other facilities of airfield infrastructure, establishment of a park of modern aircrafts, expansion of the use of new types of aircrafts (seaplanes-amphibians, ekranoplanamphibians, air-cushion take-off and landing aeroplanes, aerostatic aircrafts).

\section{Energy infrastructure}

In connection with the construction and commissioning of large mining companies a significant increase in the consumption of 
electricity and thermal energy is predicted in the region. ${ }^{24}$ The total load of the current and new consumers in the region is estimated to be 70 80 MW (excluding offshore oil extraction needs provided for by the autonomous power plant), including in the Khatanga unit - 10-15 MW, in the Popigai-Anabar-Zhilindinskyi unit - 60-70 MW. To ensure reliable and efficient power supply for new enterprises in the region, it is necessary to reconstruct the existing ones and build new electrical grid facilities.

First of all, the issue of choosing a rational scheme of power supply should be resolved. Among the main factors influencing the choice, on the one hand, are the remoteness from the points of possible connection and restrictions to connection in the power center and, on the other hand, the existence of the transport infrastructure, the possibility and the cost of fuel delivery (Ivanova et al, 2011).

In the first case, as a rule, reconstruction of the existing or construction of the new generating and power grid facilities are required, in the second case-construction of new roads (Fig. 4).

Preliminary estimates show the feasibility of formation of two autonomous power units - the Khatanga unit based on coal generation and the Anabar unit based on a small nuclear power plant (SNPP). In the first case, it will require the construction of a mini-CHP with capacity of 10-15 MW in Khatanga, in the second case establishment of a nuclear heat and power plant on the basis of a floating power unit (FPU) with the KLT-40C reactors (Fig. 5).

Along with this, there will be a phased decommissioning of the existing boilers and construction of cogenerating sources in other settlements.

Necessaryadministrativeandorganizational solutions

The scale and complexity of the project package that forms a core of the Khatanga-Anabar ATIC require adequate scientific support, as well as long-term and coordinated organizational decisions and measures enabling the effective use of the multiplicative effects of the discussed projects.

In order to establish the Khatanga-Anabar ATIC, it is necessary to find effective institutional solutions to provide multi-level, multi-faceted interactions that involve a large number of

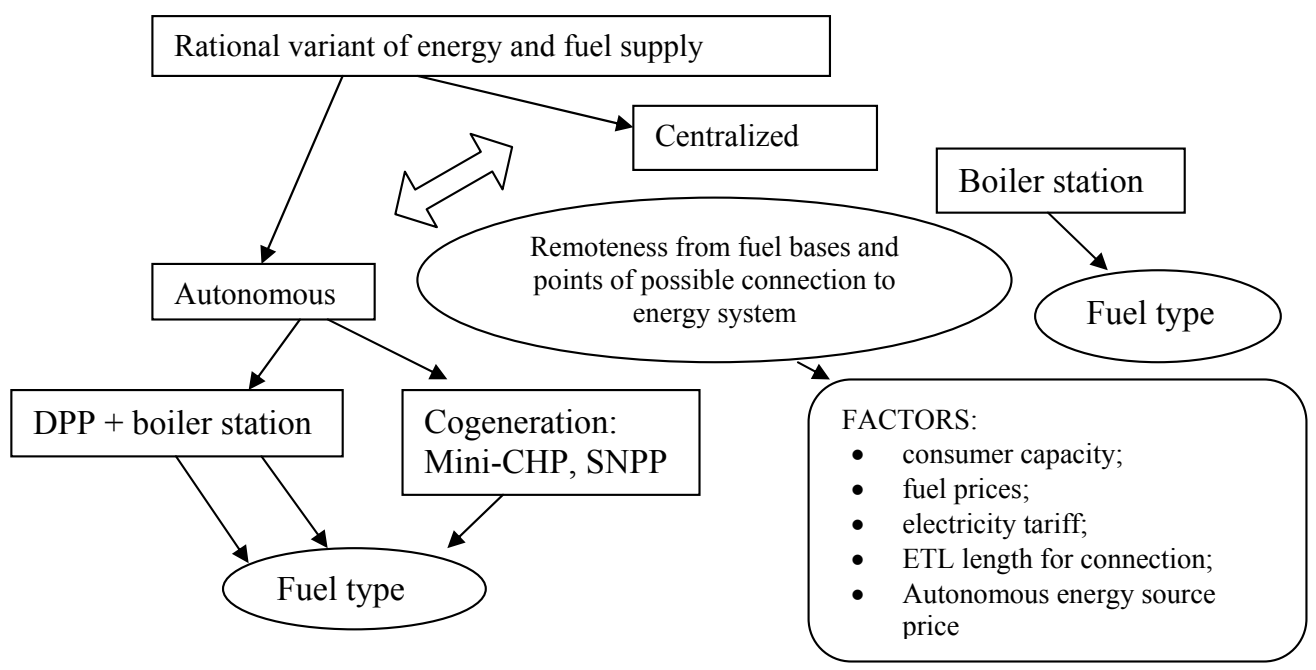

Fig. 4. Alternatives for power supply (Ivanova et al) 


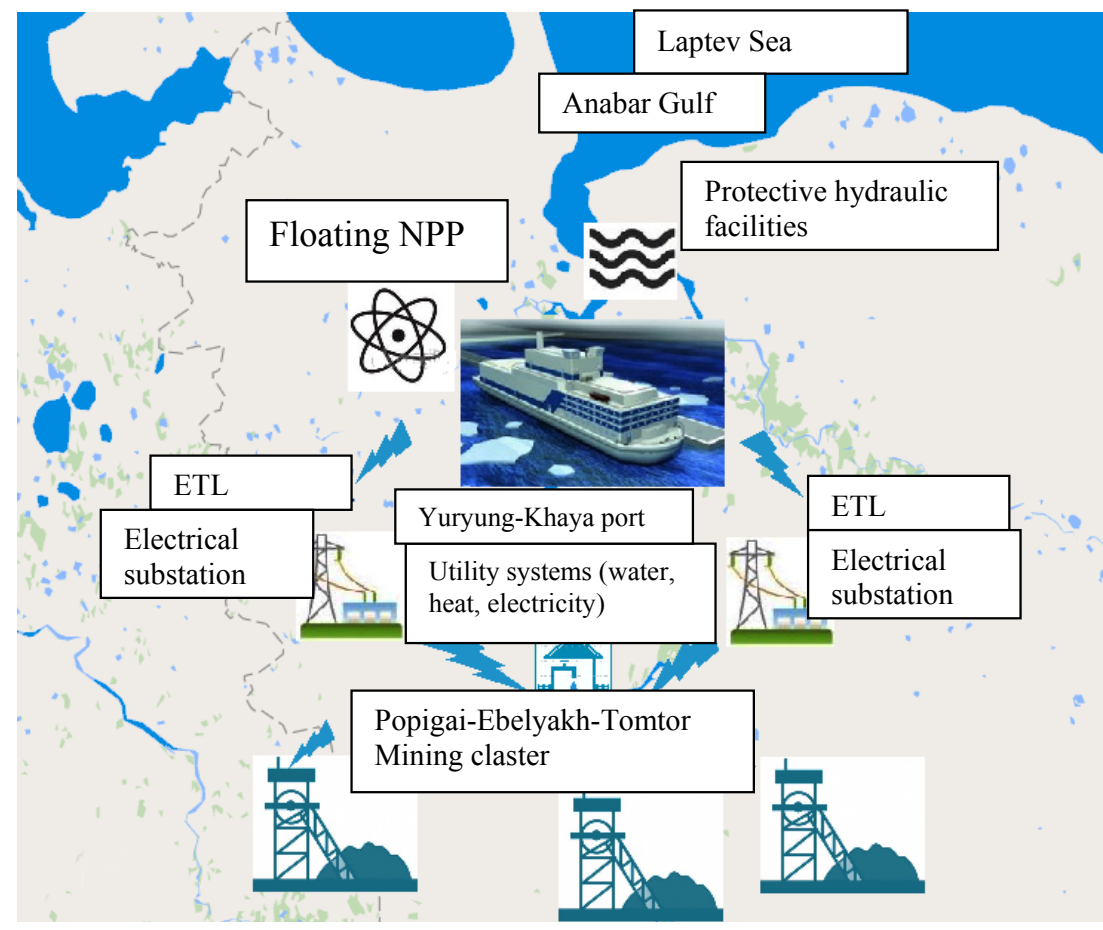

Fig. 5. Floating nuclear power plant (FNPP) in the Yuryung-Khaya port

participants. Therefore, one of the important tasks is to seek mechanisms of such interactions.

The Khatanga-Anabar ATIC that is under formation is located on the territory of the two subjects of the Russian Federation (Krasnoyarsk Territory and the Republic of Sakha (Yakutia)) that, on the one hand, have their own vision of the future and, on the other hand, have limited investment support for the new economic complex. The prospective investment projects that form the Khatanga-Anabar ATIC will be implemented by various economic entities, which complicates the process of creating an integrated transport and logistics, energy and social infrastructure.

In order to overcome the possible contradictions, to establish complex development of the territory and to reduce unproductive costs, it is necessary to consider the possibility of inclusion of the Khatanga-Anabar ATIC in the Program of Development of the Northern and Arctic territories of the Russian Federation (the state program "Social and economic development of the Arctic zone of the Russian Federation for the period till 2020"). Responsibility for the further study of the project is advisable to hand over to the federal structure at the level of the State Commission on the Development of the Arctic Region (established by the Regulation No. 228 dated March 14, 2015, the Order No. 431-p dated March 14, 2015 for interaction of federal, regional executive authorities and local governments, other government agencies and organizations in solving social and economic problems of development of the Arctic zone of the Russian Federation and national security protection).

The economic activity in the territory situated hundreds of kilometers to the east of the existing Norilsk industrial region will be the confirmation of Russia's possibility to develop the Northern and Arctic regions.

To form scientifically valid management, socio-economic and production-technological solutions it is necessary: 
- to develop and begin implementation of the research program, including geological surveys, economic and socio-economic studies, development of an integrated development strategy of the Khatanga-Anabar ATIC, assessment of potential environmental and socio-cultural consequences;

- to begin development of technological schemes, rules and strategies for implementation of investment projects on the territory of the Khatanga-Anabar ATIC;
- to develop and begin the implementation of the federal program on the use of extracted natural resources (REM, impact diamonds, etc.) to create new high-tech innovative industries;

- to create an effective organizationeconomic mechanism to improve the effects and extend the possibilities from the use of new natural materials in the economy of the country.

1 Indicators Database for municipalities [electronic resource] URL: http://www.gks.ru/free_doc/new_site/bd_munst/munst. htm (accessed August 16 2016)

Ibid.

Krasnoyarsk Territory Government Resolution No, 353-p dated July 19, 2016

Resolution of the Government of the Republic of Sakha (Yakutia) No. 166 dated May 24, 2016

5 Rating of 600 largest companies of Russia [electronic resource] URL: http://raexpert.ru/ (accessed August 16 2016); The annual report of the "Almazy Anabara" company for 2015 [Electronic resource] URL: http://alanab.ykt.ru/uploads/ files/2016/07/otchet2015.pdf (accessed August 16 2016)

6 The annual report of the "Almazy Anabara" company for 2015 [Electronic resource] URL: http://alanab.ykt.ru/uploads/ files/2016/07/otchet2015.pdf (accessed August 16 2016)

7 Indicators Database for municipalities [electronic resource] URL: http://www.gks.ru/free_doc/new_site/bd_munst/munst. htm (accessed August 16 2016)

8 The State Program "Development of production and improvement of its competitiveness" (sub-programme 15. The development of production of rare-earth metals) [electronic resource] URL: http://programs.gov.ru/Portal/programs/passport/17 (accessed August 16 2016)

9 State report "On the status and use of Russian mineral resources in 2014" (Rare-earth metals, p. 239-246) [Electronic resource] URL: http://www.mnr.gov.ru/regulatory/detail.php? ID = 143955 (accessed August 16 2016)

10 ICT Group and "Rostec" pretend to the Tomtor (April 25, 2013). [Electronic resource] URL: http://www.yktimes.ru/\%D $0 \% \mathrm{BD} \% \mathrm{D} 0 \% \mathrm{BE} \% \mathrm{D} 0 \% \mathrm{~B} 2 \% \mathrm{D} 0 \% \mathrm{BE} \% \mathrm{D} 1 \% 81 \% \mathrm{D} 1 \% 82 \% \mathrm{D} 0 \% \mathrm{~B} 8 /$ gruppa-ist-i-rosteh-imeyut-vidyi-na-tomtor/ (accessed August 16 2016)

1 Circum-Arctic Resource Appraisal: Estimates of Undiscovered Oil and Gas North of the Arctic Circle, 2008 [Electronic resource] URL: http://pubs.usgs.gov/fs/2008/3049/fs2008-3049.pdf (accessed August 16 2016)

12 Development of the Prirazlomnoe deposit [electronic resource] URL: http://shelf-neft.gazprom.ru/d/blockonthemainpage/04/4/ prezentatsiya-proekta-prirazlomnoe.pdf (accessed August 16 2016); Transport scheme of the Prirazlomnoe deposit [electronic resource] URL: https://ru.wikipedia.org/wiki/\%D0\%9F\%D1\%80\%D0\%B8\%D1\%80\%D0\%B0\%D0\%B7\%D0\% BB\% D0\% $\mathrm{BE} \%$ D0\% BC\% D0\% BD\% D0\% B0\% D1\% 8F_( $\%$ D0\% BD\% D0\% B5\% D1\% 84\% D1\% 82\% D1\% 8F\% D0\% BD\% D0\% B0 \% D1\% 8F \% D0\% BF\% D0\% BB\% D0\% B0\% D1\% 82\% D1\% 84\% D0\% BE\% D1\% 80\% D0\% BC\% D0\% B0) \#/ media / File:\% D0\% A2 \% D1\% 80\% D0\% B0\% D0\% BD\% D1\% 81\% D0\% BF\% D0\% BE\% D1\% 80\% the D1\% 82\% D0\% BD $\%$ D0 $\%$ B0\% D1\% 8F \% D1\% 81\% D1\% 85\% D0\% B5\% D0\% BC\% D0\% B0_\% D0\% BE\% D1\% 81\% D0\% B2\% D0\% BE\% D0\% B5\% D0\% BD\% D0\% B8\% D1\% 8F \% D0\% 9F\% D1\% 80\% D0\% B8\% D1\% 80\% D0\% B0\% D0\% B7\% D0\% BB\% D0\% BE\% D0\% BC\% D0\% BD\% D0\% BE \% D0\% B3\% D0\% BE_\% D0\% BC\% D0\% B5\% D1\% 81\% D1\% 82\% D0\% BE\% D1\% 80\% D0\% BE\% D0\% B6\% D0\% B4\% D0\% B5\% D0\% BD\% D0\% B8\% D1\% 8F.jpg (accessed August 16 2016)

13 "Lukoil" starts to develop an oil field in the Krasnoyarsk Territory [electronic resource] URL: http://fedpress.ru/news/ econom/industry/1450160746-lukoil-nachinaet-razrabotku-neftyanogo-mestorozhdeniya-v-krasnoyarskom-krae (accessed August 16 2016); Resolution of the Russian Government dated December 17, 2015 "On the transfer of a subsoil sector of federal importance to OJSC "NK "Rosneft”, [Electronic resource] URL: http://government.ru/docs/21193/ (accessed August 16 2016)

14 State report "On the status and use of Russian mineral resources in 2014" (Diamonds, p. 221-230) [Electronic resource] URL: http://www.mnr.gov.ru/regulatory/detail.php?ID=143955 (accessed August 16 2016)

15 The annual report of the "Almazy Anabara" company for 2015 [Electronic resource] URL: http://alanab.ykt.ru/uploads/ files/2016/07/otchet2015.pdf (accessed August 16 2016)

16 The Independent Expert Report on the reserves and resources of diamond deposits of the "Alrosa" group, chapter 11 "Economic Analysis", p.11.8 "Development of the Ebelyakh River and Goose Creek" [Electronic resource] URL: http://www. alrosa.ru/wp-content/uploads/2013/11/Alrosa_Independent_Expert_Report-2013.pdf (accessed August 16 2016)

17 Artificial diamonds will leave Yakutia without money (interview with an expert of the diamond industry, Yuri Danilov) [electronic resource] URL: http://yakutia.com/diamond/558/ (accessed August 16 2016)

18 The long-term target program "Construction of the mining site No.2 of the Kayak coal deposit" (decision of the Duma of the Taimyr Dolgan-Nenets Municipal District from 12.12.2008 No.02-0017) [electronic resource] URL: http://zakonregion3.ru/4/147741/ (accessed August 16 2016) 
19 Synthetic Diamond Market - Global Industry Analysis, Size, Share, Growth, Trends and Forecast 2015-2023 [electronic resource] URL: http://www.transparencymarketresearch.com/synthetic-diamond-market.html (accessed August 16 2016)

20 Government Report "On the condition and use of mineral resources in the Russian Federation in 2014" (Diamonds, p. 221-230) [Electronic resources] URL: http://www.mnr.gov.ru/regulatory/detail.php?ID=143955 (accessed on August 16, 2016)

21 Khatanga seaport [electronic resource] URL: http://polartrans.ru/information/morskoj-port-xatanga.html (accessed August 16 2016)

22 Territorial planning scheme of the Taimyr Dolgan-Nenets Municipal District (Volume 3) (project proposals Water, air and road transport). Federal State Unitary Enterprise Russian State Scientific-Research and Design Institute "Urbanistika", Saint-Petersburg, 2012. FGIS TP [electronic resource ] URL: http://fgis.economy.gov.ru/fgis/ (accessed August 16 2016)

23 Territorial planning scheme of the municipal district of the municipality "Anabar national (Dolgan-Evenki) Ulus (district) of the Republic of Sakha (Yakutia)", Volume 2. Materials on the justification of the scheme (Transport Section). Open Society Sahaproekt - Yakutsk, 2012, FGIS TP [electronic resource] URL: http://fgis.economy.gov.ru/fgis/ (accessed August $162016)$

24 Mel'nikov, N.N., Konukhin, V.P., Naumov, V.A., Gusak, S.A. Reactor systems for power supply of remote and inaccessible regions: the problem of choice [electronic resource] URL: http://nova.rambler.ru/ Report on the research work "Elaboration of the plan and development programme of electric power supply in Sakha Republic (Yakutia) for the period 20142018" (State contract No. 402К-Л8 dated November 12th, 2013) //L.A. Melentiev's Institute of Energy Systems of SB RAS Irkutsk, 2014 - 195 p. [Electronic resource] URL: https://www.sakha.gov.ru/files/front/download/id/1186981 (accessed August 16, 2016)

\section{References}

Pokhilenko, N.P., Kriukov, V.A., Tolstov, A.V., Samsonov, N.Iu. (2014). Tomtor kak prioritetnyi investitsionnyi proekt obespecheniia Rossii sobstvennym istochnikom redkozemel'nykh elementov [Tomtor as a priority investment project of providing Russia with its own source of rare earth elements]. In Rossiiskii ekonomicheskii zhurnal "EKO" [Russian economic magazine "ECO"]. 2, 22-35.

Iatsenko, V.A. Priority assessment of transportation of the Tomtor ore niobium-rare-earth deposit to potential enterprises of its enrichment [Otsenka prioritetnosti napravlenii transportirovki rudy niobii-redkozemel'nogo mestorozhdeniia Tomtor na potentsial'nye predpriiatiia ee obogashcheniia]. Mezhdunarodnaia nauchnaia konferentsiia "Ekonomicheskoe razvitie Sibiri i Dal'nego Vostoka. Ekonomika prirodopol'zovaniia, zemleustroistvo, lesoustroistvo, upravlenie nedvizhimost'iu" [International scientific conference "The economic development of Siberia and the Far East. Economy of natural resources, land management, forestry management, property management"], Collection of Materials, 1, 26-30.

Konoplianik, A., Buzovskii, V., Popova, Iu, Troshina, N. (2016). Vozmozhnosti i razvilki Arkticheskogo shel'fa [Opportunities and divarications of the Arctic shelf] In Neft' Rossii [Oil of Russia]. 1-2. 12-17

Kriukov, V.A., Samsonov, N.Iu., Kriukov, Ia.V. (2016). Mezhregional'nye tekhnologicheskie tsepochki $\mathrm{v}$ osvoenii Popigaiskogo mestorozhdeniia almaz-lonsdeilitovogo syr'ia [Inter-regional production chains in development of the Popigai deposit of diamond- lonsdaleite raw materials]. In Rossiiskii ekonomicheskii zhurnal "EKO" [Russian economic magazine "ECO”]. 8, 51-66

Pokhilenko, N.P., Kriukov, V.A. (2012). Strategicheskoe pozitsionirovanie Popigaiskogo mestorozhdeniia lonsdeilitov [Strategic positioning of the Popigai lonsdaleite deposit]. In Rossiiskii ekonomicheskii zhurnal "EKO" [Russian economic magazine "ECO"]. 12, 30-35

Baklanov, P.Ia. (1979). Territorial'no-akvatorial'nye ekonomicheskie raiony [Aqua-territorial economic areas]. Social and Human Sciences: XIV Pacific Scientific Congress (Khabarovsk, August 1979). Moscow, 108-110. 
Baklanov, P.Ia. (1987). Formirovanie akvaterritorial'nykh kompleksov i raionov na Dal'nem Vostoke [Formation of aqua-territorial complexes and areas in the Far East]. Maritimes regions: geographic and socio-economic development problems. Collection. Vladivostok, Far Eastern Branch of the Academy of Sciences of the USSR, 84-93.

Bondarenko, L.A., Ionova, V.D., Malov, V.Iu., Tarasova, O.V. (2012). Vozmozhnosti formirovaniia akvaterritorial'no-proizvodstvennykh kompleksov (ATPK) v zone vliianiia Severnogo morskogo puti [Potential for aqua-territorial industrial complexes (ATIC) in the zone of influence of the Northern Sea Route]. In The Asian part of Russia: modeling of economic development in the context of the experience of history (ed. Lamin, V.A., Malov, V.Iu.). Novosibirsk. Publishing House of SB RAS, chapter 11, 219-242.

Peresypkin, V., Iakovlev, A. (2006). Severnyi morskoi put' v probleme mezhdunarodnykh transportnykh koridorov. Transport Rossiiskoi Federatsii [Northern Sea Route in the problem of the international transport corridors. Transport of the Russian Federation]. 3, 17 [electronic resource] URL: http: //www.rostransport.com/transportrf/pdf/3/05.pdf (accessed 16 August 2016)

Ivanova, I.Iu., Tuguzova, T.F., Izhbuldin, A.K., Simonenko, A.N. (2011). Osvoenie mineral'nosyr'evykh resursov Severa: variant energosnabzheniia [Development of mineral resources in the North: power supply options]. Region, 4, 187-199

\title{
Предпосылки формирования
}

Арктического акватерриториально-

производственного комплекса

на основе освоения

природно-ресурсного потенциала

Хатангско-Анабарского региона

\author{
Н.Г. Шишацкий ${ }^{a}$, Е.А. Брюханова ${ }^{a}$, \\ В.С. Ефимов ${ }^{\boldsymbol{\sigma}}$, А.М. Матвеев ${ }^{\mathrm{a}}$ \\ ${ }^{a}$ Институт экономики и организаџии \\ промышленного производства СО РАН \\ Россия, 660036, Красноярск, Академгородок, 50/45 \\ ${ }^{\sigma}$ Сибирский федеральный университет \\ Россия, 660041, Красноярск, пр. Свободный, 79
}

Анализируется современное состояние и проблемы сочиально-экономического развития Хатангско-Анабарского региона, расположенного в арктической зоне Восточной Сибири на территории двух субъектов Российской Федерации (Красноярского края и Республики Саха (Якутия)), в бассейнах рек Хатанга и Анабар, впадающих в море Лаптевых Северного Ледовитого океана. Рассмотрены возможности, ограничения и перспективы реализации приоритетных инвестиционных проектов освоения минерально-сырьевых ресурсов региона. Показана целесообразность формирования акватерриториально-производственного комплекса (АТПК), основанного на использовании интегрированной транспортной логистики Северного морского 
пути и рациональных схем энергоснабжения в регионе. Рассмотрены научно-методические и организационно-экономические задачи по разработке стратегии формирования ХатангскоАнабарского АТПК.

Ключевые слова: Хатангско-Анабарский регион, инвестиционные проекты, транспортноэнергетическая инфраструктура, Северный морской путь, акватерриториальнопроизводственный комплекс (АТПК), стратегия формирования АТПК.

Исследование выполнено при финансовой поддержке РГНФ и краевого государственного автономного учреждения «Красноярский краевой фонд поддержки научной и научно-технической деятельности» в рамках научно-исследовательского проекта «Разработка долгосрочных сиенариев и организационно-экономических механизмов развития Арктической зонь Красноярского края и оченка их влияния на социально-экономическое состояние и динамику Красноярского края» (проект №16-12-24007).

Научная специальность: 08.00.00 - экономические науки. 